\title{
Acute Stimulatory Effect of Erythropoietin on Nitric Oxide Production in Human Aortic Endothelial Cells
}

Yuko Yamane, Yoshio Murakami, Michihiro Tsumori, Kunio Koshimura and Yuzuru Kato

First Division, Department of Medicine, Shimane Medical University, Izumo, Japan.

(Received 8 October 1999; and accepted 21 October 1999)

\begin{abstract}
A possible role of nitric oxide (NO), an endothelium-derived relaxing factor, in erythropoietin (EPO)-induced hypertension has been implicated. In the present study, we investigated the direct effect of recombinant human erythropoietin ( $\mathrm{rHuEPO}$ ) on NO release in human aortic endothelial cells in vitro. Treatment for $4 \mathrm{~h}$ with rHuEPO at $10^{-8}$ to $10^{-7} \mathrm{M}$ increased $\mathrm{NO}_{2}^{-}$concentration in the incubation medium of the endothelial cells. The amount of NO synthase (NOS) in the cell lysate determined by the maximal citrulline-generating activity was not changed by $\mathrm{rHuEPO}$. The effect of $\mathrm{rHuEPO}$ to stimulate NO release was abolished by anti-EPO antibody. In addition, the effect was inhibited by an intracellular $\mathrm{Ca}^{2+}$-chelating agent, BAPTA-AM. These findings suggest that EPO acutely activates NOS through an increase in intracellular $\mathrm{Ca}^{2+}$ level and consequently enhances NO production in the endothelial cells.
\end{abstract}

Prolonged treatment with recombinant human erythropoietin (rHuEPO) induces hypertension or exacerbate the preexisting hypertension in patients with chronic renal failure $(4,23)$. The effects have been attributed to an increased blood viscosity associated with a rise in the hematocrit (13), a loss of hypoxic vasodilatation (10) and a direct vasopressor effect of rHuEPO (15). Involvement of such bioactive factors as endothelin (2), prostaglandin (2) and renin-angiotensin (6) has been also suggested. In addition, a possible role of nitric oxide (NO), an endothelium-derived relaxing factor (7), in EPO-induced hypertension has been implicated $(5,12,21,22)$. It was suggested that enhanced generation of NO might prevent hypertension and mediate renal vasodilatation in rats with rHuEPO-induced erythrocytosis (22).

However, the effect of EPO on endothelial

Correspondence to: Dr Yoshio Murakami at the above address.

Phone: +81-853-20-2184, Fax: +81-853-23-8650,

e-mail: yoshiom@shimane-med.ac.jp
NOS (eNOS) activity and its mechanisms involved remain to be fully elucidated. In the present study, we investigated the possible direct effect of rHuEPO on NO release in human aortic endothelial cells in vitro. The involvement of intracellular $\mathrm{Ca}^{2+}$ was also studied in a use of an intracellular $\mathrm{Ca}^{2+}$-chelating agent.

\section{MATERIALS AND METHODS}

\section{Drugs}

rHuEPO and polyclonal anti-EPO antibody were generously provided from Chugai Pharmaceutical Inc. (Tokyo, Japan). BAPTA-AM was from Molecular Probes Inc., Eugene, OR, U.S.A.; Superoxide dismutase (SOD) from bovine liver was from Funakoshi, Tokyo, Japan; Carbacol $(\mathrm{CCH})$ was from Nacalai, Kyoto, Japan. L- $\left[{ }^{14} \mathrm{C}\right]$ citrulline was purchased from New England Nuclear, Boston, MA, U.S.A.. All the other chemicals are of the purest grade available from regular commercial sources. 


\section{Human aortic endothelial cells}

Human aortic endothelial cells (Clonetics, San Diego, CA, U.S.A.) were maintained in modified MCDB131 medium supplemented with $2 \%$ fetal calf serum, $12 \mathrm{mg} / \mathrm{L}$ bovine brain extract, $1 \mathrm{mg} / \mathrm{L}$ hydrocortisone, $10 \mu \mathrm{g} / \mathrm{L}$ human epidermal growth factor, $50 \mathrm{mg} / \mathrm{L}$ gentamycin and $50 \mu \mathrm{g} / \mathrm{L}$ amphotericin $\mathrm{B}$ in a humidified atmosphere at $37^{\circ}$ $\mathrm{C}$ under $5 \% \mathrm{CO}_{2}-95 \%$ air. After 4 to 7 passages, the cells were subcultured into poly-L-lysine coated 24-well plates and submitted to static experiments. The cells were washed three times and preincubated for $30 \mathrm{~min}$ in Dulbecco's modified Eagle's medium (DMEM). Then the cells were incubated in fresh DMEM containing $\mathrm{CCH}$, $\mathrm{rHuEPO}$, and anti-EPO antibody for $4 \mathrm{~h}$. In a set of experiments, the cells were preincubated with 2 $\mu \mathrm{M}$ BAPTA-AM for $90 \mathrm{~min}$. BAPTA-AM were first dissolved in dimetylsulfoxide (DMSO) and diluted with DMEM. The final concentration of DMSO was $0.1 \%$. The control cells were treated with $0.1 \%$ DMSO. The medium was collected and centrifuged at $10,000 \mathrm{rpm}$ for $10 \mathrm{~min}$. The resulting supernatant was stored at $-20^{\circ} \mathrm{C}$ until assayed for $\mathrm{NO}_{2}^{-}$and $\mathrm{NO}_{3}^{-}$.

Determination of medium $\mathrm{NO}_{2}^{-}$and $\mathrm{NO}_{3}^{-}$levels $\mathrm{NO}_{2}^{-}$and $\mathrm{NO}_{3}^{-}$concentrations in the medium were determined as previously described (9), using a reverse phase HPLC system combined with a cadmium-reducing column, reaction with Griess reagent and a spectrophotometer (NOD10, Eicom, Kyoto, Japan). Briefly, standard preparations containing $\mathrm{NO}_{2}^{-}$and $\mathrm{NO}_{3}^{-}(0.024$ to $1.563 \mu \mathrm{M})$ in DMEM and samples $(50 \mu \mathrm{L})$ were injected by an autosampler (AS2000, Hitachi, Tokyo, Japan). The standard preparations and the samples were kept at $4^{\circ} \mathrm{C}$ throughout the measurement. $\mathrm{NO}_{2}^{-}$and $\mathrm{NO}_{3}^{-}$were separated by a $4.6 \times 50 \mathrm{~mm}$ polystyrene polymer column. Mobile phase was $0.15 \mathrm{M} \mathrm{NaCl}, 0.15 \mathrm{M} \mathrm{NH}_{4} \mathrm{Cl}, 10 \%$ methanol containing $0.5 \mathrm{~g} / \mathrm{L}$ EDTA disodium salt (flow rate: $300 \mu \mathrm{L} / \mathrm{min}$ ). After separation, $\mathrm{NO}_{3}^{-}$was converted to $\mathrm{NO}_{2}^{-}$through a reduction column packed with fine particles of copper-plated cadmium. The effluent was reacted with Griess reagant $(5 \mathrm{~g} / \mathrm{L}$ sulfanilamide, $0.25 \mathrm{~g} /$ $\mathrm{L}$ naphtylethylenediamine, $1.25 \% \mathrm{HCl}$ ) (flow rate: $100 \mu \mathrm{L} / \mathrm{min}$ ), and absorbance at the wavelength of $540 \mathrm{~nm}$ was detected by a flow-through spectrophotometer.
The cells were washed with phosphate buffered saline (PBS, pH 7.4) and collected with $0.5 \mathrm{~mL}$ of $50 \mathrm{mM}$ Tris $\cdot \mathrm{HCl}(\mathrm{pH} 7.4)$ containing $1 \mathrm{mM}$ dithiothreitol, $1 \mathrm{mM}$ EDTA, $10 \mu \mathrm{g} / \mathrm{mL}$ leupeptin, 10 $\mu \mathrm{g} / \mathrm{mL}$ aprotinin and $1 \mathrm{mM}$ phenylmethylsulfonyl fluoride. After sonication, cells were centrifuged at $100,000 \times g$ for $30 \mathrm{~min}$ at $4^{\circ} \mathrm{C}$. Resulting supernatant was stored at $-80^{\circ} \mathrm{C}$ until assayed for NOS activity.

\section{Assay of NOS activity}

NOS activity was measured by production of $L^{-}$ $\left[{ }^{3} \mathrm{H}\right]$ citrulline from $\left.\mathrm{L}_{\mathrm{C}}-{ }^{3} \mathrm{H}\right]$ arginine. Supernatant $(50 \mu \mathrm{L})$ of cell lysate was incubated at $37^{\circ} \mathrm{C}$ for 20

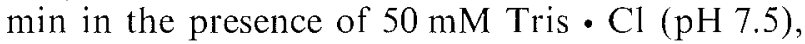
$1 \mathrm{mM}$ NADPH, $10 \mu \mathrm{M}$ flavin adenine dinucleotide, $10 \mu \mathrm{M}$ tetrahydrobiopterin, $40 \mu \mathrm{M} \quad \mathrm{L}^{-}$ arginine, $3.7 \mathrm{MBq}$ of $\mathrm{L}_{-}\left[{ }^{3} \mathrm{H}\right]$ arginine and 4 $\mathrm{mM} \mathrm{CaCl}{ }_{2}$ in a total volume of $100 \mu \mathrm{L}$. The reaction was halted by the addition of $1.25 \mathrm{~mL}$ of ice-cold $20 \mathrm{mM}$ HEPES ( $\mathrm{pH} 5.5$ ), and the total volume was applied on a Dowex- $50 \mathrm{~W} \times 8(200-$ 400 mesh, $\mathrm{Na}^{+}$form) column preequilibrated with $20 \mathrm{mM}$ HEPES (pH 5.5). The flow-through and $2 \mathrm{~mL}$ wash of distilled water were collected and the radioactivity was measured by a liquid scintillation counter. The recovery rate of citrulline determined by applying $\mathrm{L}^{-}\left[{ }^{14} \mathrm{C}\right]$ citrulline solution were $80-90 \%$. The $\mathrm{L}_{\mathrm{L}}-\left[{ }^{3} \mathrm{H}\right]$ citrulline concentration produced was corrected by the recovery rate.

\section{Protein content}

Protein content was measured using Bio-Rad protein assay with bovine serum albumin as the standard (3).

\section{Statistics}

All the results were expressed as means \pm SEM of 4-8 different experiments. The statistical difference was analyzed by ANOVA and Fisher's test. A $P$ value less than 0.05 was considered significant.

\section{RESULTS}

As shown in Fig. 1, CCH $\left(10^{-5} \mathrm{M}\right)$ increased medium $\mathrm{NO}_{2}^{-}$concentrations in human aortic endothelial cells. Treatment with rHuEPO $\left(10^{-8}\right.$ and $10^{-7} \mathrm{M}$ ) elicited a dose-related increase in 


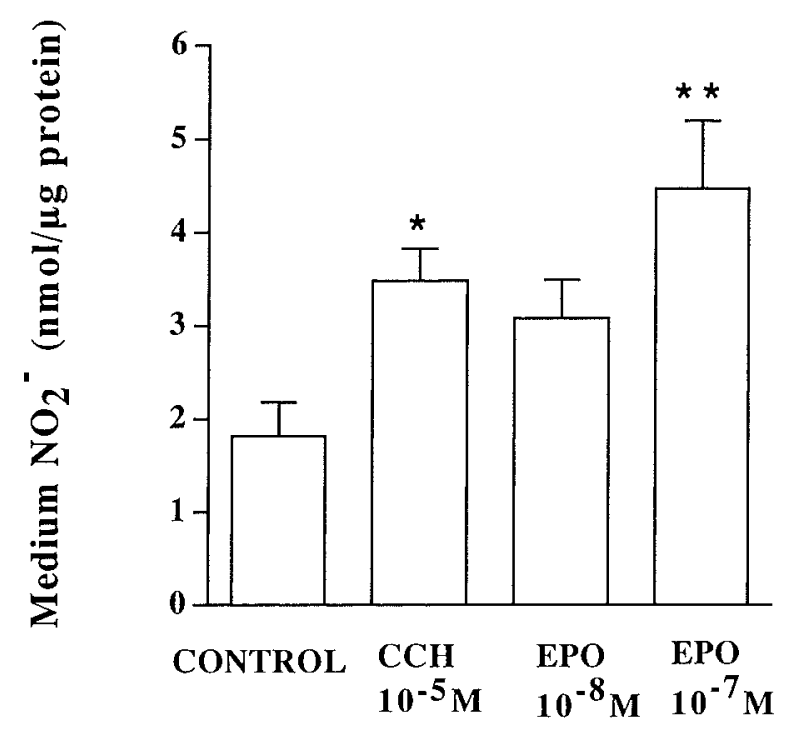

Fig. 1 Effect of recombinant human erythropoietin ( $\mathrm{rHuEPO}$ ) and carbacol $(\mathrm{CCH})$ on medium $\mathrm{NO}_{2}^{-}$ accumulation in human aortic endothelial cells. The cells were incubated for $4 \mathrm{~h}$ in the presence of $\mathrm{rHuE}$ PO $\left(10^{-8}\right.$ and $\left.10^{-7} \mathrm{M}\right)$ or $\mathrm{CCH}\left(10^{-5} \mathrm{M}\right)$. Medium $\mathrm{NO}_{2}^{-}$levels were determined by HPLC. Mean $\pm \mathrm{SE}$ values are shown. ${ }^{*}: P<0.05,{ }^{*}: P<0.01$ vs. control.

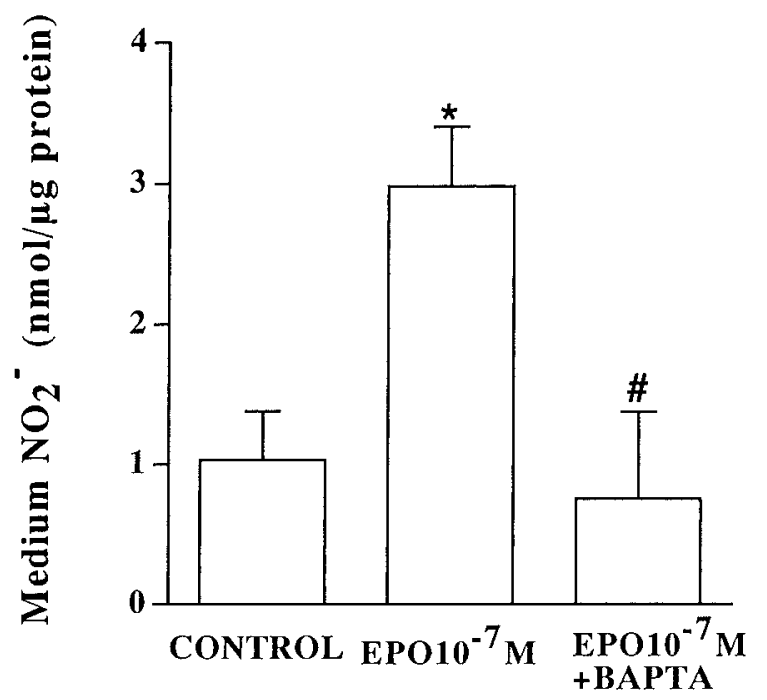

Fig. 2 Effect of pretreatment with BAPTA-AM on rHuEPO-induced $\mathrm{NO}_{2}^{-}$accumulation in human aortic endothelial cells. The cells were preincubated for $90 \mathrm{~min}$ in the presence or absence of $2 \mu \mathrm{M}$ BAPTAAM, then incubated for $4 \mathrm{~h}$ with or without rHuEPO $\left(10^{-7} \mathrm{M}\right) . \quad{ }^{*}: P<0.05$ vs control. $\#: P<0.05$ vs BAPTA-AM (-).

medium $\mathrm{NO}_{2}^{-}$levels. Medium $\mathrm{NO}_{3}^{-}$levels were not detectable in all the samples. The NOS activ- ities in the cell lysates obtained after $4 \mathrm{~h}$ incubation with $\mathrm{rHuEPO}\left(10^{-7} \mathrm{M}\right)(14.03 \pm 1.63 \mathrm{nmol} /$ $\mathrm{mg}$ protein $/ 10 \mathrm{~min}, \mathrm{n}=4$ ) were not different from control $(13.40 \pm 0.68 \mathrm{nmol} / \mathrm{mg}$ protein $/ 10 \mathrm{~min}$, $\mathrm{n}=4$ ).

The NO-producing activity of $\mathrm{rHuEPO}\left(10^{-7}\right.$ M) was inhibited in the presence of anti-EPO antibody ( $130 \pm 16 \%$ of basal vs. rHuEPO alone: $380 \pm 53 \%$ of basal, $\mathrm{n}=6, P<0.01)$. As shown in Fig. 2, pretreatment with $2 \mu \mathrm{M}$ BAPTA-AM to chelate intracellular $\mathrm{Ca}^{2+}$ inhibited the rHuEPO $\left(10^{-7} \mathrm{M}\right)$-induced NO production.

\section{DISCUSSION}

Several lines of evidence suggest that EPO stimulates $\mathrm{NO}$ synthesis in vivo. It was reported that urinary $\mathrm{NO}_{2}+\mathrm{NO}_{3}$ excretion was increased after the treatment with rHuEPO in rats $(5,17)$. Urinary cGMP excretion, a parameter of $\mathrm{NO}$ action, was also increased in EPO-treated animals (22). The mechanisms mediating the in vivo effect of EPO to stimulate NO synthesis remain to be fully elucidated. It was suggested that a rise in hematocrit induced by rHuEPO could increase blood viscosity and the vessel wall shear stress (22). The shear stress might stimulate the expression of NOS (14) and the release of NO (8). However, there have been some reports speaking against above explanation. Ni et al. (11) demonstrated in uremic rats that EPO-induced hypertension was independent on hematocrit or erythrocyte mass. Vaziri et al. (19) found a rise in plasma cGMP levels after a single injection of rHuEPO in rats. In the present study, we first found that rHuEPO raised $\mathrm{NO}_{2}^{-}$concentration in the culture medium of human aortic endothelial cells, $\mathrm{NO}_{2}^{-}$is a major metabolite of NO in serum-free aqueous solution (18). The stimulating effect of rHuEPO on NO release was inhibited by anti-EPO antibody, suggesting a specific action of EPO. Our present observation provides the first evidence that EPO directly stimulates NO production in endothelial cells. Expression of functional EPO receptor in human endothelial cells (1) supports our present observation.

There have beeen conflicting reports on the effect of rHuEPO on endothelial NOS (eNOS) expression. Ongil et al. (12) reported that rHuEPO did not modify eNOS mRNA expression in cultured bovine aortic endothelial cells. Wang and Vaziri (21) found a decrease in eNOS protein level in human endothelial cells treated with 
rHuEPO for $24 \mathrm{~h}$. In this study, we clearly demonstrated that a short-term treatment with rHuEPO increased NO production without changing the NOS amount determined by the maximal citrulline-generating activity in human aortic endothelial cells. Thus EPO, by acutely increasing the enzyme activity and chronically decreasing the protein abundance of NOS, might dually modulate NO production and might participate in complicated mechanisms in the regulation of vascular function.

In this study, the acute effect of rHuEPO to increase NO synthesis was inhibited by BAPTA$\mathrm{AM}$, an intracellular $\mathrm{Ca}^{2+}$-chelating agent. Indeed Vogel et al. (20) demonstrated that rHuEPO raised $\left[\mathrm{Ca}^{2+}\right]_{i}$ in porcine endothelial cells. The eNOS activity depends on $\mathrm{Ca}^{2+}$ and calmodulin, and insulin (24) and IGF-I (16) are known to activate eNOS in the endothelial cells through an increase in $\left[\mathrm{Ca}^{2+}\right]_{\mathrm{i}}$. Thus an increase in $\left[\mathrm{Ca}^{2+}\right]_{i}$ is the common pathway to activate eNOS for EPO and other hormones or growth factors. Interestingly, Wang et al. (21) reported that a sustained elevation of $\left[\mathrm{Ca}^{2+}\right]_{\mathrm{i}}$ induced by rHuEPO depressed eNOS expression, which was restored by a $\mathrm{Ca}$ channel blocker. Thus intracellular $\mathrm{Ca}^{2+}$ might be involved in the actions of rHuEPO to modulate both eNOS activity and expression.

In conclusion, our present findings suggest that EPO acutely activates eNOS through an increase in $\left[\mathrm{Ca}^{2+}\right]_{\mathrm{i}}$ and consequently enhances NO production in the endothelial cells.

\section{REFERENCES}

1. Anagnostou, A., Liu, Z., Steiner, M., Chin, K., Lee, E. S., Kesseimian, N. and Noguchi, C. T. (1994) Erythropoietin receptor mRNA expression in human endothelial cells. Proc. Natl. Acad. Sci. USA. 91, 3974-3978.

2. Bode-Böger, S. M., Böger, R. H., Kuhn, M., Radermacher, J. and Frölich, J. C. (1992) Endothelin release and shift in prostaglandin balance are involved in the modulation of vascular tone by recombinant erythropoietin. J. Cardiovasc. Pharmacol. 20, S25-S28.

3. Bradford, M. M. (1976) A rapid and sensitive method for the quantitation of microgram quantities of protein utilizing the principle of protein-dye binding. Anal. Biochem. 72, 248-254.

4. Buckner, F. S., Eschbach, J. W., Haley, N. R., Davidson, R. C. and Adamson, J. W. (1990) Hypertension following erythropoietin therapy in anemic hemodialysis patients. Am. J. Hypertens. 3, 947-955.

5. del Castillo, D., Raij, L., Shults, P. J. and Tolines, J. P. (1995) The pressor effect of recombinant human erythropoietin is not due to decreased activity of the endogenous nitric oxide system. Nephrol. Dial. Transplant.
10, 505-508.

6. Eggena, P., Willsky, P., Jamgotchian, N., Truckenbrod, L., Hu, M. S., Barrett, J. D., Eggena, M. P., Clegg. K., Nakhoul, F. and Lee, D. B. N. (1991) Influence of recombinant human erythropoietin on blood pressure and tissue renin- angiotensin systems. Am. J. Physiol. 261, E642-646.

7. Ignarro, L. J., Buga, G. M., Wood, K. S., Byrns, R. E. and Chaudhuri, G. (1987) Endothelium-derived relaxing factor produced and released from artery and vein is nitric oxide. Proc. Natl. Acad. Sci. USA. 84, 9265-9269.

8. Korenaga, R., Ando, J., Tsuboi, H., Yang, W., Sakuma, I., Toyo-oka, T. and Kamiya, A. (1994) Laminar flow stimulates ATP- and shear stress-dependent nitric oxide production in cultured bovine endothelial cells. Biochem. Biophys. Res. Commun. 198, 213-219.

9. Kurioka, S., Koshimura, K., Sugitani, M., Murakami, Y., Nishiki, M. and Kato, Y. (1999) Analysis of urinary nitric oxide metabolites in healthy subjects. Endocrine J. 46, $421-428$.

10. London, G. M., Zins, B., Pannier, B., Naret, C., Berthelot, J. M., Jacquot, C., Safar, M. and Drueke, T, B. (1989) Vascular changes in hemodialysis patients in response to recombinant human erythropoietin. Kidney Int. 36, 872882.

11. Ni, Z., Wang, X. Q. and Vaziri, N. D. (1998) Nitric oxide metabolism in erythropoietin-induced hypertention. Effect of calcium channel blockade. Hypertention 32, 724-729.

12. Ongil, S. L., Saura, M., Lamas, S., Puryol, M. R. and Puyol, D. R. (1996) Recombinant human erythropoietin does not regulate the expression of endothelin-1 and constitutive nitric oxide synthase in vascular endothelial cells. Exp. Nephrol. 4, 37-42.

13. Raine, A. E. G. (1988) Hypertension, blood viscosity and cardiovascular morbidity in renal failure: implications of erythropoietin therapy. Lancet i, 97-97.

14. Ranjan, V., Xiao, Z. and Diamond, S. L. (1995) Constitutive NOS expression by fluid shear stress. Am. J. Physiol. 269, H550-H555.

15. Tsukada, H., Ishimitsu, T., Ogawa, Y., Sugimoto, T. and Yagi, S. (1993) Direct vasopressor effects of erythropoietin in genetically hypertensive rats. Life Sci. 52, 1425-1434.

16. Tsukahara, H., Gordienko, D.V., Tonshoff, B., Gelato, M. T. and Goligorsky, M. S. (1994) Direct demonstration of insulin-like growth factor -I-induced nitric oxide production by endothelial cells. Kidney Int. 45, 598-604.

17. Tsukahara, H., Hiraoka, M., Hori, C., Hata, I., Okada, T., Gejyo, F. and Sudo, M. (1997) Chronic erythropoietin treatment enhances endogenous nitric oxide production in rats. Scand. J. Clin. Lab. Invest. 57, 487-494.

18. Tsumori, M., Murakami, Y., Koshimura, K. and Kato, Y. (1999) Thyrotropin-releasing hormone stimulates nitric oxide release from GH3 cells. J. Neuroendocrinol. 11, 451456.

19. Vaziri, N. D., Zhou, X. J., Smith, J., Oveisi, F., Baldwin, K. and Purdy, R. E. (1995) In vivo and in vitro pressor effects of erythropoietin in rats. Am. J. Physiol. 269, F 838-845.

20. Vogel, V., Kramer, H. J., Bäcker, A., Meyer-Lehnert, H., Jelkmann, W. and Fandley, J. (1997) Effects of erythropoietin on endothelin-1 synthesis and the cellular calcium messenger system in vascular endothelial cells. $A m$. J. Hypertens. 10, 289-296.

21. Wang, X. Q. and Vaziri, N. D. (1999) Erythropoietin depresses nitric oxide synthase expression by human en- 
dothelial cells. Hypertension 3, 894-899.

22. Wilcox, C. S., Deng, X., Doll, A. H., Snellen, H. and Welch, W. J. (1993) Nitric oxide mediates renal vasodilatation during erythropoietin-induced polycythemia. Kidney Int. 44, 430-435.

23. Winearls, C. G., Oliver, D. O., Pippard, M. J., Reid, C., Downing, M. R. and Cotes, P. M. (1986) Effect of human erythropoietin derived from recombinant DNA on the anemia of patients maintained by chronic haemodialysis. Lancet ii, 1175-1178.

24. Zeng, G. and Quon, M. J. (1996) Insulin-stimulated production of nitric oxide is inhibited by wortmannin. Direct measurement in vascular endothelial cells. J. Clin. Invest. 98, 894-898. 